\title{
Role of spermatozoa in pH stability of caudal epididymis environment
}

\author{
W.S Mahdi", S.M. Al-Shamary and Z.S. Jaafir \\ Department of Surgery and Obstetrics, Collage of Veterinary Medicine, University of Baghdad, Baghdad, Iraq \\ "email: wafer_saleh@yahoo.com
}

(Received March 21, 2018; Accepted October 28, 2018)

\begin{abstract}
50 ram testicles where been collected directly after slaughtering, preserved in cool box $\left(8-10^{\circ} \mathrm{C}\right)$ and transferred to the andrological lab at the Veterinary Medicine Collage / University of Baghdad. Samples were washed thoroughly with distal water stripped from surrounding tissues. Epididymis were separated from the entire testicles, caudae were cut out and injected with warm normal saline then sliced, $\mathrm{pH}$ was collected daily (4-5 days). Result showed that: as the preservative periods proceed, the $\mathrm{pH}$ of caudal secretions is elevated as $(6.22,6.35,6.45,6.65,6.66,6.7,6.77)$ at $(24,36,48,60,72,84,96 \mathrm{hrs})$ while total motility percentage are $(90,85,84.5,77,75,75,70 \%)$. Cold preservation after slaughtering showed decreased motility as preservation proceed as well as total alive spermatozoa decreased. In conclusion caudal secretion turned to be more acidic if cold preservation time is prolonged and total alive spermatozoa number decreased while dead one increased.
\end{abstract}

Keywords: testicle, spermatozoa, $\mathrm{pH}$, cauda, epididymis

Available online at http://www.vetmedmosul.com

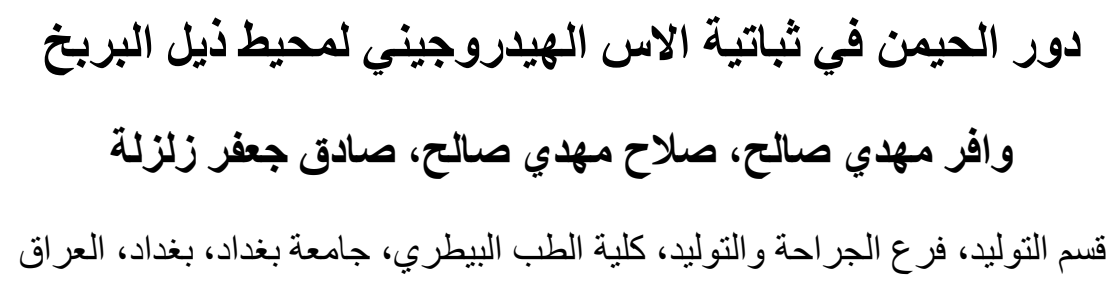

• 0 من خصى الاكباش تم جمعها بعد الذبح مباثرة، حفظت بحاويات مبردة ونقلت الى مختبر الذكورية في فرع الجراحة والته والتوليد،

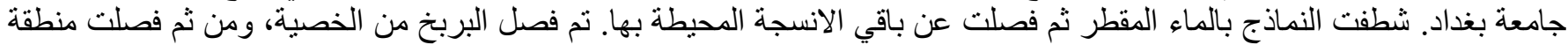

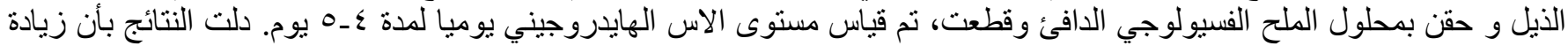

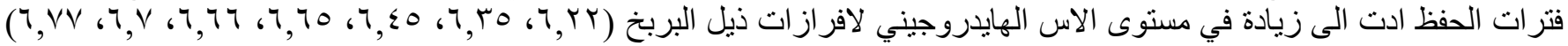

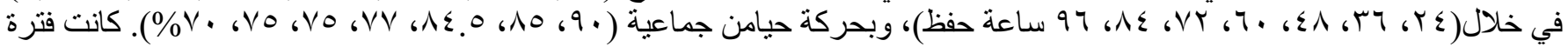

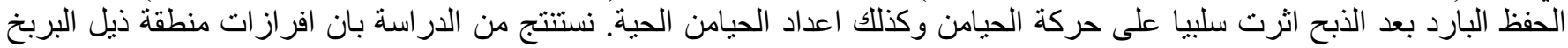
تكون اكثر حامضية بزيادة فترات الخزن المبرد ونقص في اعداد الحيامن الحية وزيادة الحيامن الميتة.

\section{Introduction}

To understand semen $\mathrm{pH}$, we need first to understand the basics of $\mathrm{pH}$. The abbreviation "pH" stands for power of Hydrogen. The " $\mathrm{H}$ " is always capitalized because it is an element symbol. $\mathrm{pH}$ is used as a scale to indicated how acidic or alkaline a solution is. It ranges from 0 to 14 , meaning that anything with a $\mathrm{pH}$ of 7 is neutral, anything above 7 is alkaline and anything below 7 is acidic. So as the $\mathrm{pH}$ number goes down, acidity increases, and vice versa (1). To look to; why semen $\mathrm{pH}$ is important? First, we have to look to the other half of the equation which is the vagina. In an ideal world, vaginal $\mathrm{pH}$ maintains a balance of good and bad bacteria, which helps prevent infections, for this reason the vaginal $\mathrm{pH}$ tends to be slightly acidic with tendency to be changed frequently, depending on the time 
of the cycle, sexual activity, even diet and exercise (2). In the most species, spermatozoa are bathed in a fluid of its reservoir where they remained immobile and with a low level of metabolism, this immotile status is important to preserve the sperm energy reserve and to decrease the risk of alteration to its membranes, internal structures or even its biochemical compounds by endogenous oxidizing agents produced by mitochondrial activity (3). This quiescent phase can be of different lengths and finishes when the semen is released to the external environment (ejaculation) where the spermatozoa become motile and metabolically active (4). The activation of sperm motility occurs in response to changes in the external medium and some external factors, among those factors, ions and particularly internal $\mathrm{pH}(\mathrm{pHi})$. This sperm $\mathrm{pHi}$; seem to play a pivotal role in sperm physiology (5). Mammalian spermatozoa obtained from the testis are immotile; to become motile (and fertile) they must undergo first a post-gonadal maturation in the epididymal tubule (6). Spermatozoa when passed through the epididymis, the composition of the medium surrounding them is greatly modified and can be part of the motility process; this is mainly due to epididymal cell- lining epithelium secretions (7). In many species spermatozoa remain immotile in the lower part of the epididymis and are activated during ejaculation when spermatozoa are mixed with the secretions of the accessory glands (8).

The $\mathrm{pH}$ of the epididymal cauda secretions is acidic (or slightly acidic) in the most species, for this external spermatozoon $\mathrm{pH}(\mathrm{pHe})$ acts directly on internal spermatozoa $\mathrm{pH}$ (pHi) (9). A pHi alkalization stimulated both metabolism and motility of epididymal bull spermatozoa. Protein phosphorylation, dependent upon changes in bull sperm $\mathrm{pH}$, has also been reported (10). The mechanism of implication in the regulation of the sperm $\mathrm{pH}$ in ram spermatozoa, showed that; external potassium has been acted on pHi through a complex mechanism involving calcium (11) Analysis of the $\mathrm{pH}$ of ram spermatozoa diluted in different ionic conditions (with or without sodium and potassium ions) has also shown that the $\mathrm{pH}$; is strongly dependent upon the pHe and that it increases linearly with $\mathrm{pHe}$ (9). A great suggestion demonstrated that; the mammalian sperm membrane is permeable to protons, related to a large change in $\mathrm{pHe}$ which produces changes in pHi that cannot be over ridden by the pHi regulatory mechanisms which may exist.

In mammals, ejaculated spermatozoa, are motile but unable to fertilize mature oocyte, they must undergo a capacitation step occurred in the female genital tract which is the prelude to the acrosome reaction in the egg zona pellucida (12). External calcium is required for both capacitation and the acrosome reaction, but several other factors, e.g. the $\mathrm{pH}$ of the medium, the presence of glucose, external potassium and bicarbonate, are also involved, sperm $\mathrm{pHi}$, the $\mathrm{Na}^{+} / \mathrm{K}^{+}$-ATPase, a proton ATPase, and CaATPase are also cellular mechanisms that have been implicated as factors in this phenomenon (13). Recent studies have also suggested that the increase of $\mathrm{pH}$ during capacitation is more likely to be an accompanying phenomenon rather than the trigger of this physiological step (14) (Figure1). Luminal environment required for sperm storage in the cauda is contributed mainly for fertilizing ability of spermatozoa. Moreover, this ability would be make-up of; ions, small organic molecules, proteins and glycoproteins, sperm cells created conditions that allowed the ability to be hold in a quiescent state for long period (15), changes in $\mathrm{pH}$ (in the several species) have been proposed to modulate this event that is controlled by the sperm's cells (16).

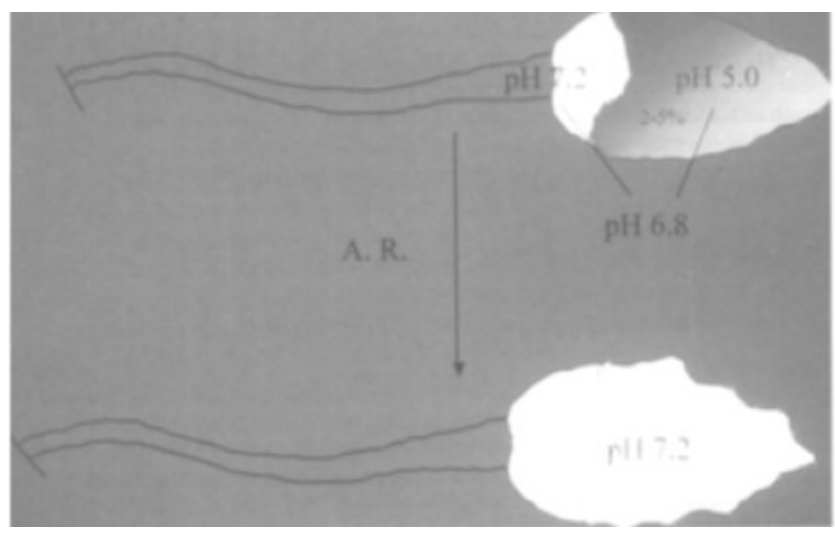

Figure 1: Hypothetical pathway of the sperm internal $\mathrm{pH}$ changes during the acrosome reaction (AR) (28).

The neutral caudal $\mathrm{pH}$ of 6.8-7.0 where the most spermatozoa enzymes are in the best active, therefore, deviation towards alkalinity or acidity can reduce metabolic rate. So; it has been suggested that spermatozoa have the active role in controlling this deviation if occurred (15). The declined $\mathrm{Na}^{+} / \mathrm{K}^{+}$-ATPase activity at acidic $\mathrm{pH}$ 5.5- 5.7 result in decreased sperm movement and capacitation, in which it interfered with the fertilization process and could be one of the mechanisms of male infertility (17).

The ability of mature mammalian spermatozoa to maintain a coordinated and forward motility is dependent upon intracellular free $\mathrm{Ca}_{2}^{+}$, at the level of the flagellar plasma membrane this could be achieved by two systems: (a) an ATP requiring $\mathrm{Ca}^{+}{ }_{2-}$ pump; (b) a $\mathrm{Na}_{2}^{+} /$ $\mathrm{Ca}^{+}{ }_{2}$ antiporters (18). Sperm of all mammalian species use a flagellum for swimming. Mammalian sperm has a centrally located 9+2 arrangement of microtubule doublets and hundreds of accessory proteins that together constitute an axoneme, these all possess the sperm flagellum variety of functions contributed mainly for environments arrangement (19). The inhibition of motility of the spermatozoa in the 
caudal epididymis is due to an acidic $\mathrm{pH}$, in which; this deprived spermatozoon motility that might lead to increase environmental acidic $\mathrm{pH}$ came either from decrease spermatozoa activity or dead sperms (20), in another term; flagellar movement of sperms diminished or stopped which affect the environmental $\mathrm{pH}$. Seminal plasma is a mixture of secretions from the testes, epididymis and accessory sex glands, contains $\mathrm{HCO}_{3}-/ \mathrm{CO}_{2}$, inorganic ions, organic acids, sugars, lipids, steroids, amino acids, polyamines, nitrogenous bases and proteins. Semen has a very high buffering capacity, higher than that of most other body fluids, therefore, the $\mathrm{pH}$ of the seminal fluid may play a significant role not only in maintaining the viability and quality of the sperm, but also in ensuring fertilization, the effects of $\mathrm{pH}$ on sperm movement (which mainly arranged by sperm motility) is of great important (21).

\section{Materials and methods}

50 ram testicles (2-3 year of age) were collected directly after slaughtering, preserved in cool box $8-10^{\circ} \mathrm{C}$, and transferred to the lab for further processing. Testicular samples and due to its consistency ready to damage and corrupted if not preserved well, period of time followed slaughter must be minimized to shortness period of time to overcome this effect (22). As far as, slaughtered ram age affects the spermatozoa parameters, age of donor ram was adjusted according to the teeth count (23). Testicle samples were washed with distils water firstly, then with normal saline supplement with $100 \mathrm{IU} / \mathrm{ml}$ penicillin and $0.1 \mathrm{mg} / \mathrm{ml}$ streptomycin for disinfection (24). Entire testicles then separated from the epididymis using surgical curved scissors. Cauda epididymis then separated from entire epididymis (Figure 2, 3 and 4).

Tail of epididymis (cauda) was separated from the whole epididymis and submitted to multiple injunctions with normal saline then sliced to small pieces (Figure 5).

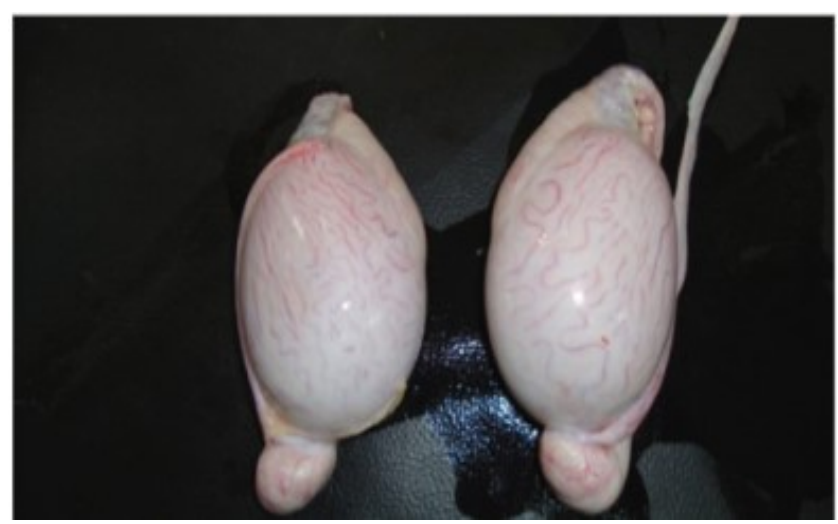

Figure 2: two testicular samples after slaughter.

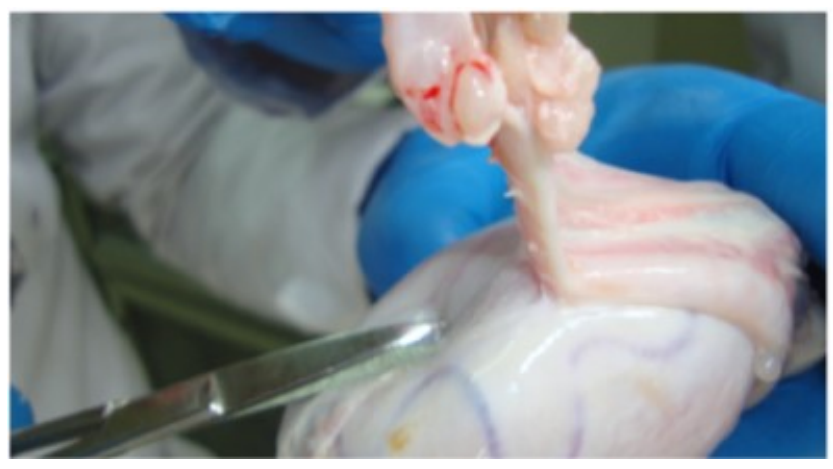

Figure 3: Two testicular samples after surrounded tissues removed and washed.

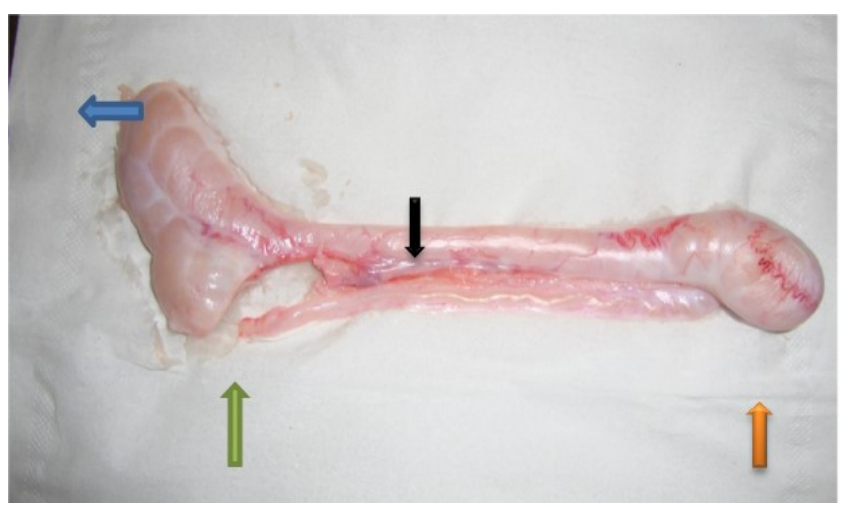

Figure 4: Separated epididymis; head (blue), body (black) and tail (orange) of the epididymis, Vas deferens (green).

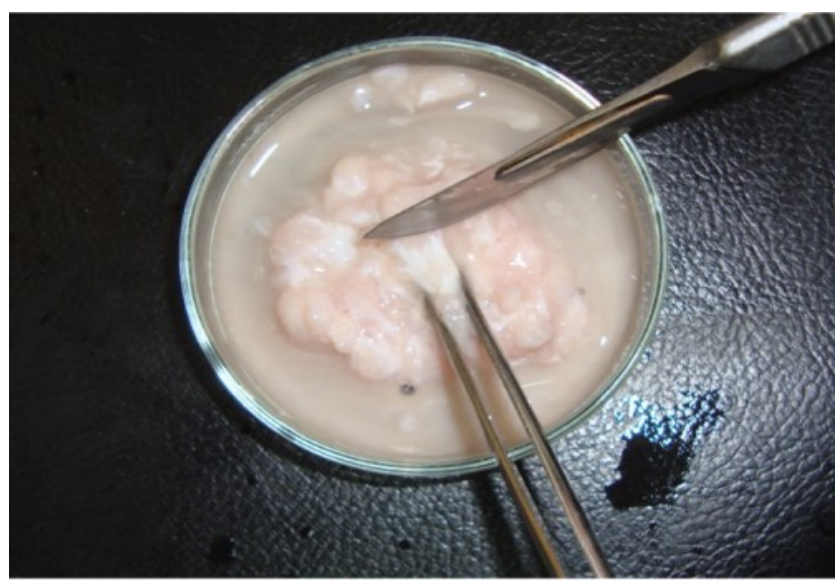

Figure 5: Slicing of cauda of epididymis.

Cauda contents put in the test tubes, $\mathrm{pH}$ was calculated by $\mathrm{pH}$-meter, and stained slides with Eosin-Nigrosine stain for spermatozoa dead or alive count every 12 hours all samples were preserved in $4-8{ }^{\circ} \mathrm{C}$ refrigerator, all results were recorded. 


\section{Results}

Results showed that; at time of collection spermatozoa total motility was about $90 \%$ and $\mathrm{pH}$ was $6.2-6.5$, it starts to elevate slightly as time of cold preservation progress to reach about 6.7-6.9 after $132 \mathrm{hrs}$, and a reduction in viability to less than $50 \%$ as demonstrated in diagram 1 and 2. Period from time of collection at abattoir toward time of processing at Lab was also determined diagram 3, spermatozoa motility decreased as time passed.

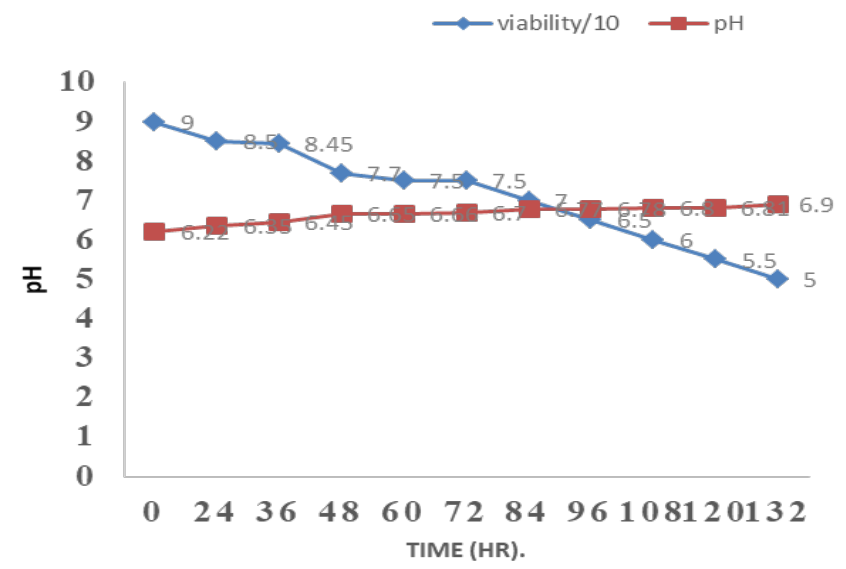

Diagram 1: The effect of cauda $\mathrm{pH}$ of on sperm viability.

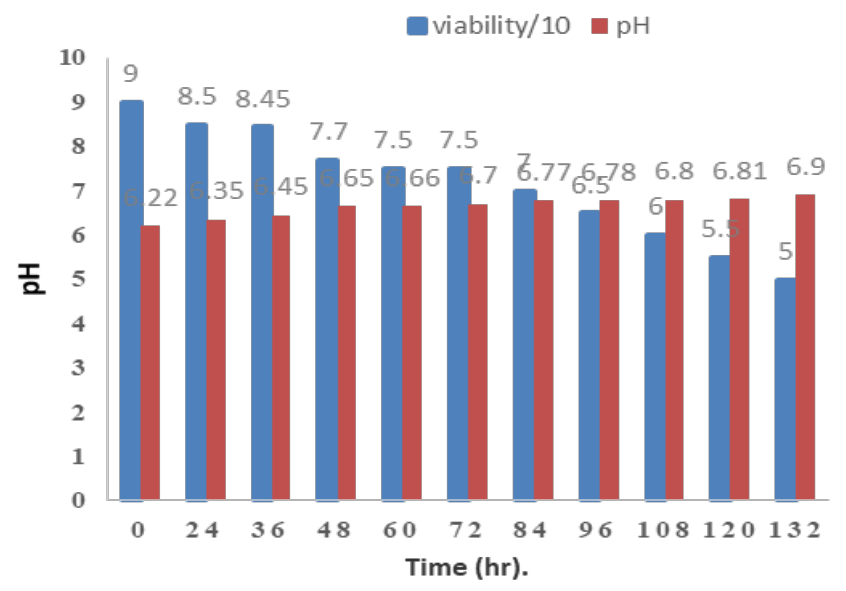

Diagram 2: The effect of cauda $\mathrm{pH}$ of on sperm viability.

\section{Discusion}

This study is designed to investigate the rule of spermatozoa upon its preservation inside the tail (cauda) of epididymis possess the ability to control its internal $\mathrm{pH}$ and be able to arrange the external surrounded $\mathrm{pH}$, in a manner that can save itself life or its fertilizable activites. Results showed that; external $\mathrm{pH}(\mathrm{pHe})$ changed from time of collection toward processing in the lab, acidic reaction $\mathrm{pH}$ could be increased as time of spermatozoa preservation prolonged. (9) agree with this finding in which there was an obvious elevation toward acidity of spermatozoa $\mathrm{pH}$ as time apart sharply from time of collection until processing events start at lab.

(18) put his approval as; changing in $\mathrm{pH}$ of caudal secretion toward acidity is started as time elapsed from collection to processing is prolonged, in which, the acidity index is turned to be elevated if the samples undergo long term cold preservation.

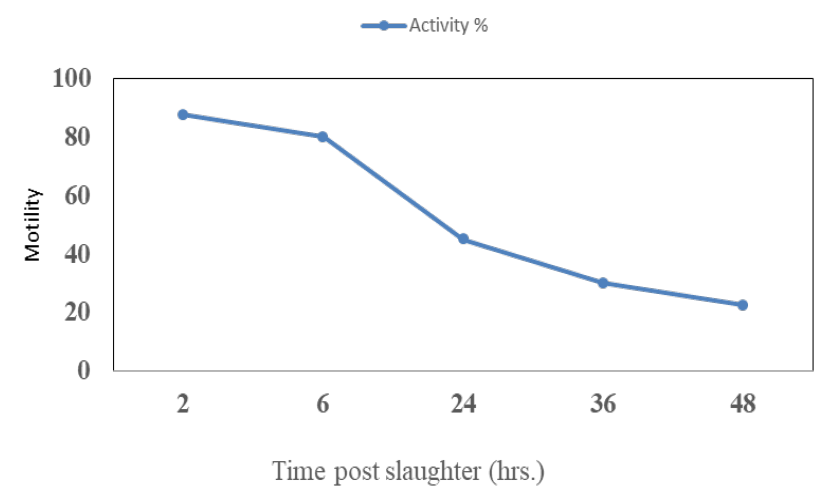

Diagram 3: The effect of time elapses from sperm collection until processing on motility.

As far as the controlling of caudal secretion $\mathrm{pH}$ is well tolorated and adjusted by spermatozoa, an acidic luminal $\mathrm{pH}$ is involved for its maturation-maintenance and its immotile state in the epididymis. Failure of the acidification mechanism might result in poor sperm maturation, premature motility and infertility. (25) agree with this finding, in which, the less motile or even immotile caudal spermatozoa is very important for the future activity upon ejaculation and vas deferens crossing toward female tract.

For the most species, spermatozoa remain immotile in the lower part of the epididymis, even when they have gained the capability to be fully motile as shown by dilution in an adequate medium in vitro. In vivo, motility is activated when the spermatozoa are mixed with secretions from the different accessory glands during ejaculation, (26) approved this, in which many enviromental factors played as activators of sperm motility and metabolism improvment of different species, specially the changes in sperm internal $\mathrm{pH}(\mathrm{pHe})$ and its regulation in activation of sperm axonemal movement which is very important upon its fertilizable index.

The spermatozoa environment plays an important role in the development of their fertilizing ability. Among the external factors known to act on spermatozoa physiology, 
ions which have a pivotal role, this external $\mathrm{pH}(\mathrm{pHe})$ might affect sperm motility, (1) put his agreement and give a best example involving ions which is the activation of the sea urchin spermatozoa at dilution, Sea urchin spermatozoa are immotile and without oxygen consumption in the coelomic fluid. Their mobility as well as their metabolism are turned on at spawning in sea water by a rise in internal $\mathrm{pH}(\mathrm{pHi})$ induced by the activation of a sodium-proton exchan controlled by the plasma membrane potential.

(2) approved that; the pHi also plays a role in modulating mammalian spermatozoa motility and fertilizability index, inwhich rat spermatozoa can arranged its membrane poteitial toward a sodium-proton membrane exchange mechanism and can induce an increase in $\mathrm{pHi}$ which modulate its mobility.

Internal $\mathrm{pH}(\mathrm{pHi})$ has its rule in increasing the motility of spermatozoa when cooperate with external $\mathrm{pH}(\mathrm{pHe})$ arranged by epididymal cauda spermatozoa this is well approved by (27) in ram and (2) in bull spermatozoa.

(21) suggested that; no specific $\mathrm{pH}$ regulatingmechanisms is present, in which, it is possible to measure the internal $\mathrm{pH}$ of spermatozoa, internal $\mathrm{pH}$ was found to be dependent upon the $\mathrm{pH}$ of the external medium for that, a quasi-linear relationship exists between the internal and external $\mathrm{pH}$, so no specific $\mathrm{pH}$ regulatory-mechanisms is demonstrated as the ions (protons) are passively distributed.

There is a correlation between the $\mathrm{pH}$ externa $(\mathrm{pHe})$ or the environmental $\mathrm{pH}$ where sperm found and the iternacellullar $\mathrm{pH}(\mathrm{pHi})$, spermatozoa modulates this correlation to its own benifite. (29) demostrated and approved this correlation on his study upon sea urchin sperm, and the relation associated with motility initiation and acrosome reaction. This uptake ratio was essentially constant over a wide range of probe and sperm concentrations. Addition of $\mathrm{Na}^{+}$to sperm suspended in $\mathrm{Na}^{+}-$ free sea water (medium) resulted in activation of motility, this acidification could be blocked by mitochondrial inhibitors or $\mathrm{Ca}_{2}^{+}$uptake blockage which accomplished with activites failure. (30) approved that; sperm cell provides an ideal model system for evaluating $\mathrm{pH}$, measurement techniques, sperm cell is unique in that its functional status can be easily and continuously monitored by means of its motility, which is directly affected by $\mathrm{pH}$.

\section{References}

1. Shapiro BM, Schackmann RW, Tombes RM, Kazazoglou T. Coupled ionic and enzymatic regulation of sperm behavior. Curr Top Cell Reg. 1985;26:97-113.

2. Wong PYD, Lee WM, Tsang AYF. The effects of extracellular sodium on acid release and motility initiation in rat caudal epididymal spermatozoa in vitro. Exp Cell Res. 1981;131:97-104.

3. Acott TS, Carr DW. Inhibition of bovine spermatozoa by cauda epididymal fluid: II. Interaction of $\mathrm{pH}$ and a quiescence factor. Biol Reprod. 1984;30:926-935.
4. Ickowicz D, Finkelstein M, Breitbart H. Mechanism of sperm capacitation and the acrosome reaction: role of protein kinase. Asian J Androl. 2012;14:816-82.

5. Hermo L, Adamali HI, Andonian S. Immuno-localization of CAП and $\mathrm{H}+\mathrm{V}$ - ATPase in epithelial cells of the mouse and rat epididymis. $\mathrm{J}$ Rol. 2000;21:376-391.

6. Yanagimachi R. Mammalian fertilization. In: Knobil E, Neill JD, Ewing L, editors. The Physiology of Reproduction. New York: Raven Press Ltd; 1994. p. 189-232.

7. Hermo L, Robaire B. Epididymis cell types and their function. In: Robaire B, Hinton B, editors. The epididymis from molecules to clinical Practice. New York: Kluwer Academic Plenum; 2002. p. 81102.

8. Sekoni VO, Rekwot PI, Bawa EK, Barje PP. Effects of age and time of sampling on serum Testosterone and spermio-gram of Bunaji and N'Dama bulls. Sci Alert. 2008;50:55.

9. Gatti JL, Chevrier C, Paquignon M. Relation between internal $\mathrm{pH}$ (pHi) and motility of ram and boar spermatozoa. In: Baccetti B, editor. Comparative Spermatology 20 Years After. New York: Raven Press; 1993. p. 369-372.

10. Carr DW, Acott TS. Internal $\mathrm{pH}$ regulates bovine sperm motility and protein phosphorylation. Biol Reprod. 1989;41:907-920.

11. Rigoni F, Dell P, Deana R. Evidence for a D pH-driven $\mathrm{Ca}_{2}{ }^{+}$uptake in EGTA-treated bovine spermatozoa. Eur J Biochem. 1987;169:417422.

12. Breitbart H, Rubinstein S, Lax Y. Regulatory mechanisms in acrosomal exocytosis. Rev Reprod. 1997;2:165-174.

13. Kopf GS, Kalab P, Leclerc P. Signal transduction in mammalian spermatozoa. In: Verhoen G, Habenicht UF, editors. Molecular and cellular endocrinology of the testis. Berlin: Springer-Verlag; 1994. p. 153-183.

14. Uguz C, Vredenburgh WL, Parrish JJ. Heparin-induced capacitation but not intracellular alkalization of bovine sperm is inhibited by RpAdenosine-3,5-cyclicmonophosphorothioate. Biol Reprod. 1994;51:1031-1039.

15. Carr DW, Usselmann MC, Acott TS. Effects of $\mathrm{pH}$, lactone and viscoelastic drag on sperm motility "species comparison". Biol Reprod. 1985;33:588-595.

16. Pastor SN, Beautieu V, Litvin TN, DaSilva N, Brown D, Buck J, Levin LR, Breton S. Bicarbonate- regulated adenyle cyclase (sAC) is a sensor that regulates $\mathrm{pH}$ dependent V- ATPase recycling. J Biol Chem. 2003;278:49523-49529.

17. Ji Z, Li C, Jie L, Hongjun L, Zhiwei H, Min X, Shengrong C, Bing $\mathrm{Y}$. The semen $\mathrm{pH}$ affects sperm motility and capacitation. PLoS ONE. 2015;10(7):e0132974.

18. Bradley MP, Forrester IT. A sodium-calcium exchange mechanism in plasma membrane vesicles isolated from ram sperm flagella. Febs Let. 1980;12(1):15-18.

19. Lindemann CB, Lesich KA. Functional anatomy of the mammalian sperm flagellum. Cytoskeleton. 2016;73(1):652-669.

20. Samir H, Jean-Luc G. Role of the ionic environment and internal $\mathrm{pH}$ on sperm activity. Europ Soci Hum Reprod Embryo Hum Rep. 1998;13(4):20-30.

21. Ji Z, Li C, Jie L, Hongjun L, Zhiwei H, Min X, Shengrong C, Bing Y. The semen $\mathrm{pH}$ affects sperm motility and capacitation. PLoS ONE. 2015;10(7): e0132974.

22. Lones FA, Islam R, Khan MZ, Sofi KA, Khan I. Effect of postmortem time on the quality of ram cauda epididymal spermatozoa. Indian J Small Rum. 2011;17(2):174-177.

23. Karja NWK, Fahrudin M, Setiadi MA. Invitro fertility of post-thawed epididymal ram spermatozoa after storage at 5 before cryopreservation. Media Peternakan. 2013;36(1):26-31.

24. Sylvie B, Peter JS, Smith BL, Dennis B. Acidification of the male reproductive tract by a proton pumping $\left(\mathrm{H}^{+}\right)$-ATPase. Nat Med. 1996;2:470-472. 
25. Huang R, Sun LP. Effects of different $\mathrm{pH}$ conditions and inorganic positive ions on the sperm motility of anodonta woodiana pacifica houde. J Fuzhou Teachers Coll. 2001;20:5.

26. Liu LD, You Y. Effects of different $\mathrm{NaCl}$ concentrations and $\mathrm{pH}$ conditions on the Sperm motility of across ochetlius hemispinus. Fujian Prov Anim Husb Vet. 2010;32:4.

27. Hamamah S, Gatti JL. Role of the ionic environment and internal $\mathrm{pH}$ on sperm activity. Hum Reprod. 1998;13(1):20-30.
28. Babcock DF, Rufo GA, Lardy HA. Potassium-dependent increases in cytosolic $\mathrm{pH}$ stimulate metabolism and motility of mammalian spermatozoa. Proc Nail Acad Sci. 1983;50:1327-1331.

29. Gatti JL, Chevrier C, Paquignon M, Dacheux JL. External ionic conditions, internal $\mathrm{pH}$ and motility in ram and boar spermatozoa. J Reprod Fert. 1993;98:439-449.

30. Hon CL, Carl J, David E. Changes in internal $\mathrm{pH}$ associated with initiation of motility and acrosome reaction of sea urchin sperm. Develop Biol. 1983;95(1):31-45. 